\title{
Effect Of Body Weight Resistant Exercises By Trx Tool On Some Physical Abilities And The Performance Level Of Fundamental Technical Apparatus For Rope "Dr/ Amal salah sorour
}

\section{Introduction and the problem of research:}

Fitness is an important requirement for the daily life of the ordinary people and it is an essential requirement to conduct the sports activity, our common enduring need fitness and varies according to the burden on the organs of the body involved in the performance of the activity.

Humans seeks to acquire fitness with various possible ways, the tools and equipments assistance developed working to strengthen both big and small muscular, such as (TRX) using body weight resist it differ from any other fitness devices and tools due to its small weight and the ability to move from one place to another, it also allows everyone to develop the upper part muscles of the body as well as the lower part muscles of the body. (6)

According to Bliss (2005) that the exercises TRX depend on the body weight and the power of the person instead of relying on the devices or weightlifting, it develop the Force, capacity, balance, flexibility, compatibility muscular nervous system ,and flat core muscles.

The training of TRX includes exercises for muscles to strengthen the core part of the body to link between the upper and lower part of the body. (2), (10)

technical rhythmic exercises is an academic term in physical education faculty for rhythmic gymnastics, according to the FIG, roop is one of the tools of rhythmic

Assistant professor, at exercise, gymnastics department- faculty of physical education, Monofiya University. 
gymnastics five tools (rope, hoop, ball, clubs, ribbon), it requires to judge performance of the fundamental technical apparatus and other apparatus by jump (passing through roop - all throw and catch or by one of them). (5)

That requires high muscular strength from arms, legs, abdomen muscles, and the control of fingertips (fingers' muscles) on rope during the variety of the performances of jumping to avoid obstruct the body with the rope as well as not to lose the rope during jumping as well as through and catch.

The muscular strength is an important determinant in achieving the best sport performance, the more the compatibility between the muscles that leads the movement participation in the kinesthetic performance and the counter muscles, the more the muscular strength increase. (9:195)

through the researcher work in rhythmic technical exercises department for females' in the third year of
Physical Education Faculty, Monofiya University, she noted that the students after teaching them the uses of rope tool, and when tested them to perform with music, she found that some of the students don't have good control on the tool and this is due to the weakness of the exercises followed the development of the elements of the fitness required to good performance such as muscular strength (arms, legs, abdomen) and Compatibility nerves system's muscles. Which lead to fail in the performance requirements or core groups to the rope in unity with the law of FIG which is passing through the rope (jump). Throw and catch (all the rope or one part of them).

as the warm-up and physical preparation of the supplement for the teaching of the exercise of the technical rhythmic lead freely without devices or tools to assist, where students are inside the teaching halls for the rhythm technical exercises and which are difficult to support it with large equipments and devices, so the 
researcher found that its easy to use TRX for training by using body weight resistant its safer and secure and portable and also it's the most suitable way to improve some physical abilities of fitness and affecting the performance of the fundamental technical apparatus and other apparatus for the rope.

the objective of the research: Identify the impact of training using body weight resistant using TRX:

1. Some of the physical abilities of affecting the basic requirements of the rope in the technical rhythmic exercise (arms' muscular strength legs' muscular strength- the abdomen muscles power Compatibility).

2. The performance level of some technical fundamental of the rope in the rhythmic technical exercise under discussion (passing through the rope - Throw and catch)

\section{The imperatives of research:}

1. There are significant differences median function between pre and post indices and dimensional of control group in some of the physical abilities under discussion and the performance level of the technical fundamental of the rope under discussion for the benefit of post measurement.

2. There are significant differences median function between pre and post indices and dimensional of experimental group in some of the physical abilities under discussion and the performance level of some of the technical fundamental of the rope under discussion for the benefit of post measurement.

3. There are significant differences median function between pre and post indices and dimensional of control and experimental groups in some of the physical abilities under discussion and the performance level of some of the technical fundamental of the rope under discussion for the benefit of the control Group.

The terminology used in the research:
1. Total body resistant exercise TRX : 
Is kind of exercise using the gravity and the body weight to build the force, capacity, flexibility, balance, and compatibility between nervous system muscles and the core muscles, using a tool called TRX.

It is a two-rope, not flexible, along $2.5 \mathrm{~m}$. and $4 \mathrm{~cm}$, grip handle to put on it the feet and hands to carry the body weight, and Iron clips to put it on the bar (figure 1)

\section{Suspension Anchor}

2. Intermediate Anchor Loops

3. Anchor Carabiner

4. Bottom Anchor Loop

5. Main Carabiner

6. Equalizer Loop

7. Locking Loop

8. Mid Length Marks

9. Adjustment Tabs

10. Cam Buckles

11. Handles

12. Foot Cradles

13. Main Straps (6)

(Figure 1)

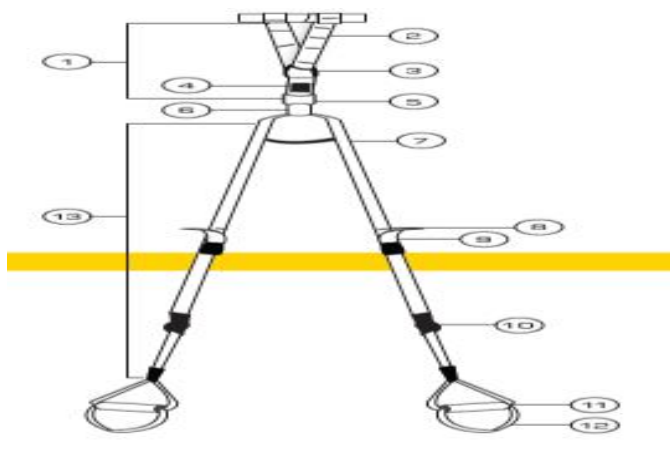




\section{r) Fundamental Apparatus Technical Groups and other Technical Groups: ${ }^{*}$}

this is the basic skills for using rope (Passing through the rope) and other technical groups are common apparatus with rhythmic gymnastics tools(rope, hoop, ball, clubs, ribbon) that is (Throw and catch) .(5)

\section{Research procedures:}

First: Research Method:

Researcher used experimental curriculum using experimental design to one experimental group and the other is control group, by the pre and post measurements.

Second: The Research Sample:

The research sample from students in the third year of

** (procedural definition)
Physical Education Faculty, Monofiya University enrolled in the academic year 2012/2013, (74) female students, (20) female students have been revoked from the research sample.

Third: Research Sample:

selected by planned way of female students of the third year of Physical Education Faculty, Monofiya University, 40 female by $54.05 \%$ of the research sample divided the sample Randomly to two groups, one experimental group (20) student, and the other control group (20) student 
Table (1)

Moderation distribution of the sample research Growth variables and physical abilities and the skill variables of the rope under discussion $(\mathrm{N}=60)$

\begin{tabular}{|c|c|c|c|c|c|}
\hline \multicolumn{2}{|c|}{ Variables } & Mean & median & $\begin{array}{c}\text { Std. } \\
\text { Deviation }\end{array}$ & Skewness \\
\hline \multirow{3}{*}{$\begin{array}{l}\text { Growth } \\
\text { variables }\end{array}$} & Length & $174 . V V O$ & $17 \varepsilon .$. & $\varepsilon .990$ & 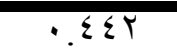 \\
\hline & Weight & $09.5 \ldots$ & $7 . \ldots$ & V.Y.T & $\because 199$ \\
\hline & Age & $19.1 \ldots$ & $r \cdot \cdots$ & $\because \varepsilon \cdot 0$ & $-1.009-$ \\
\hline \multirow{3}{*}{$\begin{array}{l}\text { Physical } \\
\text { abilities }\end{array}$} & $\begin{array}{c}\text { Muscle } \\
\text { strength of legs } \\
\text { dynamometer } \\
(\mathrm{kg})\end{array}$ & Tr.YTV & 71 . YO. & $1 . \lambda r T$ & 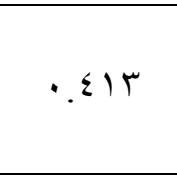 \\
\hline & $\begin{array}{c}\text { Muscle } \\
\text { strength of } \\
\text { arms } \\
\text { dynamometer } \\
(\mathrm{kg}) \\
\end{array}$ & $11.01 r$ & II. & $.97 \varepsilon$ & $\because 0 \leq 7$ \\
\hline & $\begin{array}{c}\text { Strength of } \\
\text { abdominal } \\
\text { muscles } \\
\text { Sit from lie } \\
\text { down } \\
(r \cdot s)\end{array}$ & $1.0 \ldots$ & $1 . r 90$ & .94. & $.0 \leq 1$ \\
\hline \multirow{3}{*}{$\begin{array}{c}\text { Skill } \\
\text { variables }\end{array}$} & $\begin{array}{l}\text { Compatibility } \\
\text { Jump with } 60 \\
\text { cm rope } \\
\text { (correct number) }\end{array}$ & 1. & $1 \ldots$ & $\cdot \varepsilon \wedge r$ & $.70 \leqslant$ \\
\hline & $\begin{array}{l}\text { passing } \\
\text { through the } \\
\text { rope through } \\
\text { jump (mark) }\end{array}$ & 7.1 To & ฯ... & 1.9. & $\cdot r \leq$. \\
\hline & $\begin{array}{l}\text { Throw and } \\
\text { catch (mark) }\end{array}$ & $7 . \leqslant \vee 0$ & $v_{.} .$. & 1.187 & -סטזים \\
\hline \multicolumn{3}{|c|}{$\begin{array}{l}\text { In table (1) that all the } \\
\text { les of transactions }\end{array}$} & \multicolumn{3}{|c|}{$\begin{array}{l}\text { skewness calculated confined } \\
\text { between } \pm 3 \text { demonstrating the }\end{array}$} \\
\hline \multicolumn{4}{|c|}{ Assiut Journal For Sport Science Arts } & & \\
\hline
\end{tabular}


moderation distribution of the the variables under discussion. sample individuals searching in

\section{Table (2)}

Equality of the two sets of research in the variables under discussion $(\mathbf{N} 1=\mathbf{N} 2=20)$

\begin{tabular}{|c|c|c|c|c|c|c|}
\hline \multirow{2}{*}{\multicolumn{2}{|c|}{ Variables }} & \multicolumn{2}{|c|}{ Control group } & \multicolumn{2}{|c|}{ Experimental group } & \multirow{2}{*}{$\mathrm{T}$} \\
\hline & & mean & deviation & Mean & deviation & \\
\hline \multirow{3}{*}{$\begin{array}{c}\text { Growth } \\
\text { variables }\end{array}$} & Length & $17 \% . V 0$. & $0.1 \leqslant 9$ & $17 \pi . \wedge .$. & $\leqslant .979$ & $\because \mu^{\mu}$ \\
\hline & Weight & 09.10. & $V . \leqslant 0 V$ & 09.50. & V.IT & $\because \leqslant \mu$ \\
\hline & Age & 19.10. & rit. & 19.10 & $\varepsilon \leqslant \leqslant$. & $\because V V V$ \\
\hline \multirow{3}{*}{$\begin{array}{l}\text { Physical } \\
\text { abilities }\end{array}$} & $\begin{array}{c}\text { Muscle } \\
\text { strength of } \\
\text { legs } \\
\text { dynamometer } \\
(\mathrm{kg})\end{array}$ & $7 Y . Y 10$ & $1 . \wedge \wedge 7$ & • & $1 . \wedge \cdot \varepsilon$ &. .111 \\
\hline & $\begin{array}{c}\text { Muscle } \\
\text { strength of } \\
\text { arms } \\
\text { dynamometer } \\
(\mathrm{kg})\end{array}$ & $11 . \leqslant 71$ & $.91 r$ & 11.001 & 1. ro & $\because r q r$ \\
\hline & $\begin{array}{l}\text { Strength of } \\
\text { abdominal } \\
\text { muscles } \\
\text { Sit from lie } \\
\text { down(20s) }\end{array}$ & $1.0 \wedge \wedge$ & $\cdot 9 \leq r$ & $1 \cdot . \leqslant 11$ & qr. & $.09 \mathrm{~V}$ \\
\hline \multirow{3}{*}{$\begin{array}{c}\text { Skill } \\
\text { variables }\end{array}$} & $\begin{array}{l}\text { Compatibility } \\
\text { Jump with } \\
60 \mathrm{~cm} \text { rope } \\
\text { (correct } \\
\text { number) }\end{array}$ & $1 . \varepsilon \ldots$ & $.0 \cdot r$ & $1 .$. & $\because \leqslant V$. & .70. \\
\hline & $\begin{array}{l}\text { passing } \\
\text { through the } \\
\text { rope through } \\
\text { jump (mark) }\end{array}$ & $7.1 \ldots$ & 1.170 & 7.10 & $1 . \varepsilon \cdot$ & $.1 \leq r$ \\
\hline & $\begin{array}{l}\text { Throw and } \\
\text { catch (mark) }\end{array}$ & $7 . \leqslant 0$. & $1 . T / V$ & $7.0 \ldots$ & 1.01 & سTH \\
\hline
\end{tabular}


The value of $(\mathrm{T})$ when tabulated $0.05=2.042$

In table (2) that all the values of $\mathrm{T}$ calculated the variables under discussion between the measurements of the two (control-experimental) groups less than the value of the $\mathrm{T}$ Tabular trend display and which reached $(2.042)$ at the level of the moral 0.05 demonstrating the equalization of the two sets of research in those variables.

\section{The causes of the sample selection:}

Students of the third college year applied to them a fundamental technical exercise which includes the skills' performance and the uses of the rope (4)

Fourth: ways of collecting data:

Devices and tools used in the research application:

- rest meter device to measure the length

- Medical scale to measure weight in kilograms

Physical tests applied in research: attachment (1)
- Dynamometer to measure muscle strength (of legs and arms) (4:211)

- $\quad$ Sit from lying down with knees bent to measure the strength of the abdominal muscles test. (4: 241)

- $\quad$ Test skipping rope five times in a row with no disruption in performance to measure compatibility. (5:320) Skill tests applied in research:

The researcher designed to measure the performance level of skill Form Facility, attachment (2), were presented to the expert in the rhythmic gymnastics facility attachment (3), for an opinion, and pointed to the validity of the form after making the modification by the (redistribution of grades on the axes

\section{Fifth: the exploratory study:} The researcher conducting the survey from Tuesday 12/2/2013 to Thursday $14 / 2 / 3013$ on the exploratory sample of 20 
female students from the research community and not from the research sample, in order to

- $\quad$ Ensure the validity and calibration of instruments and tools used in the research.

- $\quad$ Providing places for the TRX tool

- Training assistants on ways to test procedures.

- $\quad$ Ensure the availability of security and safety factors.

- The discovery of the difficulties that may arise during the application.

- The possibility of implementation of the proposed program.

- The appropriateness of training time for unity.

Sixth: Scientific transactions of the physical tests:

1. Honesty tests the physical and skill performance evaluation form:

using Honesty was performed comparison to 20 students from the research community and from outside the sample sincerity had been held on Saturday, 16/02/2013, and Table 3 shows that

Table (3)

Honest physical tests applied in the research by marginal honesty comparison $(\mathrm{N} 1=\mathrm{N} 2=7)$

\begin{tabular}{|c|c|c|c|c|c|}
\hline \multirow{2}{*}{$\begin{array}{c}\text { Physical } \\
\text { tests }\end{array}$} & \multicolumn{2}{|c|}{ Upper quarter } & \multicolumn{2}{|c|}{ Lower quarter } & \multirow{2}{*}{$\mathbf{T}$} \\
\hline & median & deviation & median & deviation & \\
\hline $\begin{array}{l}\text { sitting from } \\
\text { lying }\end{array}$ & $11.7 \cdot V$ & $\cdot .7 \leqslant$. & 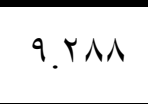 & $.11 r$ & $9 . \cdots$ \\
\hline $\begin{array}{l}\text { jump with } \\
\text { rope }\end{array}$ & $r . .$. & $\because \cdots$ & $1 \ldots$ & $\because \cdots$ & $9 . \cdots$ \\
\hline $\begin{array}{c}\text { Passing } \\
\text { through rope }\end{array}$ & $v .1 \leqslant r$ & $\cdot r \vee \wedge$ & $0 . Y \wedge T$ & .901 & $\{. \wedge \cdot 1$ \\
\hline $\begin{array}{l}\text { Throw and } \\
\text { catch rope }\end{array}$ & 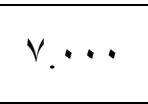 & $.0 \mathrm{VV}$ & $0 . \cdots$ & $1 . r q$. & $r . v \cdot \varepsilon$ \\
\hline
\end{tabular}

T. tabular value at the abstract level $0.05=1.943$

Assiut Journal For Sport Science Arts 
In table (3) that there are differences with statistical significance between upper quarter and lower quarter where the value of calculated T. Tabular is more than the display T. Tabular, which amounted to 2.447 at the level of abstract 0.05, which demonstrates that the honesty test being able to distinguish between the members of the upper and lower quarters levels.

2. Tests the physical stability of form skill performance evaluation:

The procedure using stability (test and re-test) its application had been held on Tuesday, $19 / 02 / 2013$, and the table (4) explains that

\section{Table (4)}

The stability of physical tests applied in the research by the manner test application and re-applying it $(\mathrm{N} 1=\mathrm{N} 2=20)$

\begin{tabular}{|c|c|c|c|c|c|}
\hline \multirow{2}{*}{$\begin{array}{c}\text { Physical } \\
\text { tests }\end{array}$} & \multicolumn{2}{|c|}{ First measure } & \multicolumn{2}{|c|}{ Second measure } & \multirow{2}{*}{$\mathbf{R}$} \\
\hline & median & deviation & median & deviation & \\
\hline $\begin{array}{l}\text { sitting from } \\
\text { lying }\end{array}$ & $\cdot 9 \leq r$ & $\cdot Y M$ & .990 & מצT & $\cdot \wedge 97$ \\
\hline $\begin{array}{l}\text { jump with } \\
\text { rope }\end{array}$ & .01. & $. .11 \leq$ & .01. & $.1 \leq 1$ & .717 \\
\hline $\begin{array}{c}\text { Passing } \\
\text { through rope }\end{array}$ & 7.00 & .999 & 7.10 & $1 . \varepsilon \cdot$ & $\because V \cdot r$ \\
\hline $\begin{array}{l}\text { Throw and } \\
\text { catch rope }\end{array}$ & ᄀ. . . & 1.4 & 7. Yo. & $.97 V$ &.$V 77$ \\
\hline
\end{tabular}

R. tabular value at the abstract $0.05=0.444$

It is clear from table (4) that all the values of correlation between the application of the first and second measurement physical tests are higher than the value of displayed T. Tabular, which amounted to 0.632 at the abstract level 0.05 .

The difference between the first and the second measurements are statistically function where all the values of calculated T. Tabular are less 
than the value of the displayed T. Tabular, which amounted to 2.262 at the abstract level 0.05 , which indicates the stability of the test.

Seventh: The application of the proposed exercise of body weight resistance using TRX tool:

- The researcher found that after access to scientific references and through its experience in teaching assistant professor of the rhythmic technical exercises of fitness to identify the needed and wanted performance of each of the various ways of rope jump, throw and catch.

- The researcher has compiled the exercises of body weight resistant using TRX tool had taken into account that the appropriate exercises to female students.

- $\quad$ Five of the TRX had settled in teaching classes of rhythmic technical exercises; researcher had taken care of security and safety elements.

- $\quad$ Students continued using the TRX exercises by body weight resistant for 12 week and 24 educational unit by twice a week and the total unity (90 minutes), in the part of the preparation for the physical compile (25 minutes).

- It was applicable in the second part of the second semester of the academic year 2012/2013, where the curriculum is divided into two parts:

- Part I: free rhythmic technical exercises studied for 6 weeks.

- Part II: rhythmic technical exercises with instruments studied for another 6 weeks The following table shows the model of the study unit. 
Table (5)

Study unit model

Unit no.: thirteen

date: $09 / 04 / 2013$

week no.: seventh

Educational goal: - education of some leaps for rope exercises

Physical goal: development of muscle strength of upper and lower part and compatibility

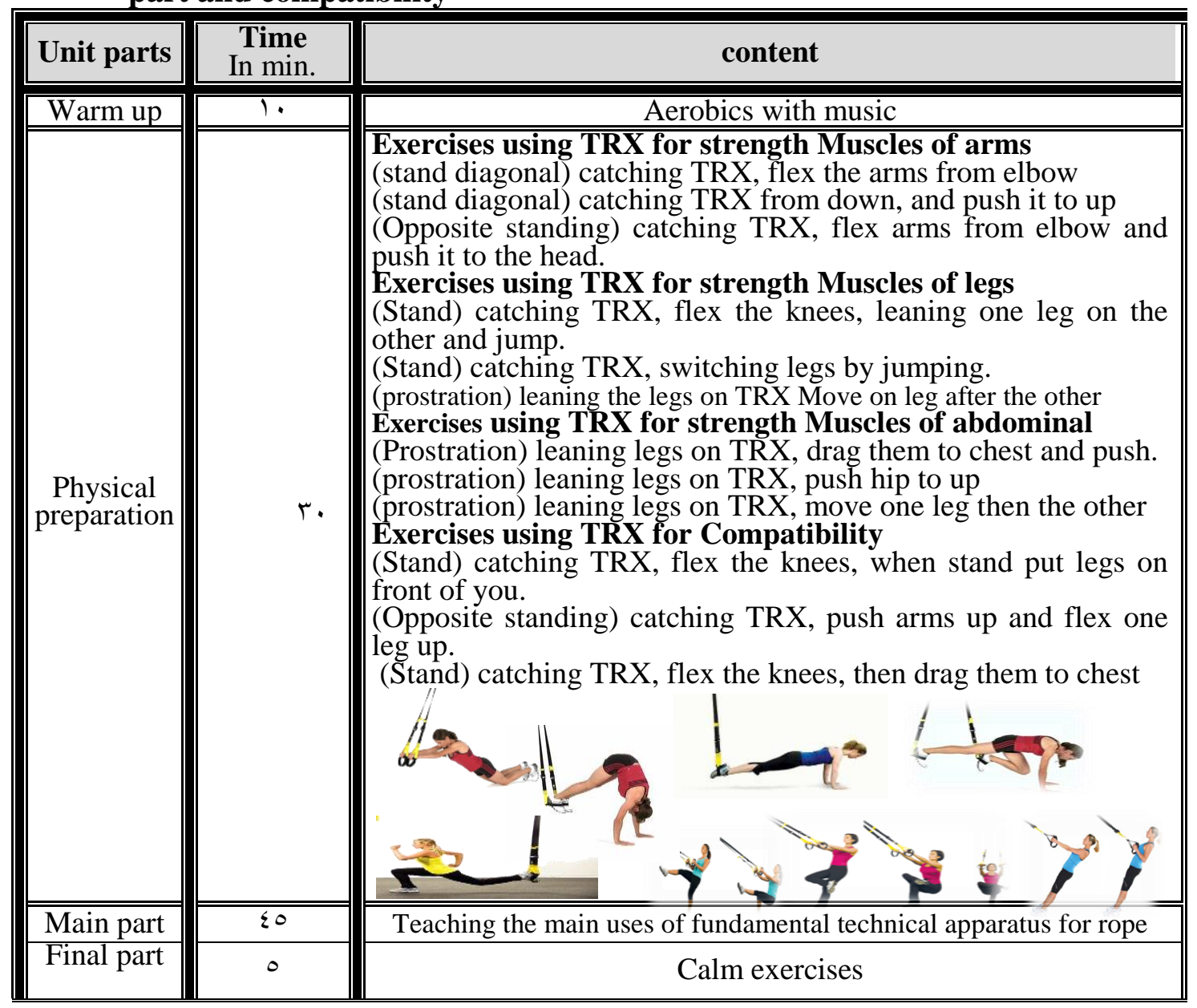

Assiut Journal For Sport Science Arts 
Eight: the steps of the Executive research

a) Pre measurement:

Measurements were conducted for the two experimental and control group in the following physical tests

Muscle strength (arms - legs abdomen) and compatibility neuromuscular on Sunday 24/02/2013, and skill measurements on 25/02/2013

b) The core implementation of the study:

Basic experiment was conducted from Tuesday 26/2/2013 to Sunday 19/5/2013 for 12 weeks by two units per week and the number of 24 units teaching total unit time (90 minutes) in the physical preparation part for (25 minutes).

c) Post measurement:

After the completion of the period specified for the application of TRX exercises, the researcher conducted post measurements of the two groups of experimental and control research in some physical abilities in fitness under discussion and the level of performance skills through judgments. On Monday 20/05/2013 and Tuesday 21/05/2013.

Ninth: Statistical Treatments:

- Mean

- Median

- Standard deviation

- Skewness

- The correlation coefficient

- $\quad$ Value (T)

- $\quad$ Percentage

Tenth: Results and discussion:

1) discussion of the results of the first hypothesis 
Table ( 7 )

Significant differences in the two measurements (pre and post) for the control group in physical abilities and skill variables $(\mathrm{N}=\mathbf{2 0})$

\begin{tabular}{|c|c|c|c|c|c|c|c|}
\hline \multirow{2}{*}{\multicolumn{2}{|c|}{ Variables }} & \multicolumn{2}{|c|}{ Pre measure } & \multicolumn{2}{|c|}{ Post measure } & \multirow{2}{*}{$\begin{array}{c}\text { Improvement } \\
\% \\
\end{array}$} & \multirow{2}{*}{$\mathrm{T}$} \\
\hline & & mean & deviation & mean & deviation & & \\
\hline \multirow{3}{*}{ 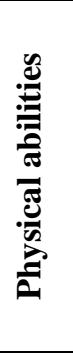 } & $\begin{array}{l}\text { strength of legs } \\
\text { dynamometer } \\
(\mathrm{kg})\end{array}$ & $T r . Y 10$ & $1 . \wedge \wedge 7$ & $77.9 \leq 1$ & $1.9 \vee \leqslant$ & V.71\% & $1 \cdot . r \wedge r$ \\
\hline & $\begin{array}{l}\text { strength of arms } \\
\text { dynamometer }(\mathrm{kg})\end{array}$ & 11.571 & .914 & 10.000 & $\cdot \varepsilon \leqslant r$ & एo. $า \leqslant \%$ & $17.00 \mathrm{~V}$ \\
\hline & $\begin{array}{c}\text { Strength of } \\
\text { abdominal } \\
\text { muscles } \\
\text { Sit from lie } \\
\text { down }\end{array}$ & $1 . .011$ & $\cdot .9 \leq r$ & אדצ.זו & $\because 1 \cdot v$ & r. r. & $1 T . \varepsilon r Y$ \\
\hline \multirow{3}{*}{ 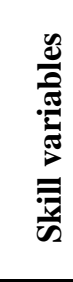 } & $\begin{array}{l}\text { Compatibility } \\
\text { Jump with } \\
\text { rope }\end{array}$ & $1 . \varepsilon \cdots$ & $.0 . r$ & $r .1 \ldots$ & $\cdot r \cdot \Lambda$ & $0 . \ldots \%$ & $0 . \leqslant \wedge$. \\
\hline & $\begin{array}{l}\text { Jump through } \\
\text { rope }\end{array}$ & $7.1 \ldots$ & 1.170 & $11 \ldots$ & .911 & A. rr\% & 10.975 \\
\hline & $\begin{array}{l}\text { Throw and } \\
\text { catch }\end{array}$ & $7 . \leq 0$. & I.M & $11 . \varepsilon$ & 1.90 & $\vee 7 . \vee \leqslant \%$ & $10 . \times 9$ \\
\hline
\end{tabular}

T. tabular value at the abstract level $0.05=2.042$

It is clear from table (6) that 0.05 . Researcher returns that to there are significant differences between the averages of the two measurements pre and post for the control group and in favor of post measurement, as the value of $T$. calculated is greater than the value of $T$. displayed, which amounted to 2.042 at the abstract level of the differences to the using of the free and traditional physical exercises in the preparation phase of the rhythmic technical exercises throughout the semester for 3 months.

2) discussion of the results of the second hypothesis 
Table ( $\mathrm{V})$

Significant differences in the two measurements (pre and post) the experimental group in variables $(\mathrm{N}=20)$

\begin{tabular}{|c|c|c|c|c|c|c|c|}
\hline \multirow{2}{*}{\multicolumn{2}{|c|}{ Variables }} & \multicolumn{2}{|c|}{ Pre measure } & \multicolumn{2}{|c|}{ Post measure } & \multirow{2}{*}{$\begin{array}{c}\text { Improvement } \\
\%\end{array}$} & \multirow{2}{*}{$\mathrm{T}$} \\
\hline & & mean & deviation & mean & deviation & & \\
\hline \multirow{3}{*}{ 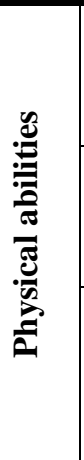 } & $\begin{array}{c}\text { strength of } \\
\text { legs } \\
\text { dynamometer } \\
(\mathrm{kg})\end{array}$ & Tr.T & $1 . \wedge$. & VT.rv & $1 . \varepsilon$. & $\% \backslash \vee . \vee \varepsilon$ & rะ.Vq \\
\hline & $\begin{array}{c}\text { strength of } \\
\text { arms } \\
\text { dynamometer } \\
(\mathrm{kg})\end{array}$ & 11.07 & $1 . \cdot \varepsilon$ & 19.40 & $1 . r$ & $\% 77.09$ & $r r . v q$ \\
\hline & $\begin{array}{l}\text { Strength of } \\
\text { abdominal } \\
\text { muscles } \\
\text { Sit from lie } \\
\text { down }\end{array}$ & $1 \cdot . \leqslant 1$ & .94 & IV.Yq & .79 & $\% 77.11$ & ro.rVI \\
\hline \multirow{3}{*}{ 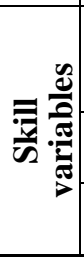 } & $\begin{array}{c}\text { Compatibility } \\
\text { Jump with } \\
\text { rope }\end{array}$ & I.r. &.$\leqslant V$ & r.10 & $\cdot r v$ & $\% 197.10$ & 17.717 \\
\hline & $\begin{array}{c}\text { Jump through } \\
\text { rope }\end{array}$ & 7.10 & $1 . \cdot \varepsilon$ & 17.1. & .10 & $\% 171 . \vee 9$ & ґА.Аঙ \\
\hline & $\begin{array}{l}\text { Throw and } \\
\text { catch }\end{array}$ & 7.0 & 1.0 & $17 . \cdots$ & $\cdot V T$ & $\% 1 \leq 7.10$ & $r \leqslant . \vee q r$ \\
\hline
\end{tabular}

T. tabular value at the abstract level $0.05=2.042$

It is clear from table (7) that there are significant differences between the averages of the two measurements (pre and post) in the experimental group and in favor of post measurement, as the value of $T$. calculated is greater than the value of $\mathrm{T}$. displayed, which amounted to 2.042 at the abstract level of 0.05 . Researcher returns that to the differences in physical changes to the use of TRX exercises using body weight resistance in preparation phase for rhythmic technical exercise lessons for 3 months, and also to the diversity of exercises using the TRX because it is multi-level themes. Researcher returns these differences in skills due to the variables as to take advantage of the TRX 
exercises to improve physical capacity and thus improve performance skills; she also gives them the challenge and insists with the thrill factor for the students.

3) Discussion of the results of the third hypothesis

Table $(\wedge)$

Significant differences in the two measurements differences (pre and post) between the two groups (experimental control $)(\mathbf{N} 1=\mathbf{N} 2=20)$

\begin{tabular}{|c|c|c|c|c|c|c|c|c|}
\hline & \multirow[b]{2}{*}{ Variables } & \multicolumn{3}{|c|}{ Control group } & \multicolumn{3}{|c|}{ Experimental group } & \multirow[b]{2}{*}{$\mathrm{T}$} \\
\hline & & $\begin{array}{l}\text { Improvement } \\
\text { average }\end{array}$ & $\begin{array}{c}\text { Deviation } \\
\text { Improvement } \\
\text { Average }\end{array}$ & $\begin{array}{l}\text { Improve- } \\
\text { ment } \\
\text { percentage }\end{array}$ & $\begin{array}{l}\text { Improvement } \\
\text { average }\end{array}$ & $\begin{array}{c}\text { deviation } \\
\text { Improveme- } \\
\text { nt } \\
\text { average } \\
\end{array}$ & $\begin{array}{c}\text { Improveme- } \\
\text { nt } \\
\text { percentage }\end{array}$ & \\
\hline \multirow{3}{*}{ 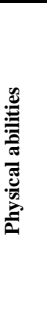 } & $\begin{array}{c}\text { strength of } \\
\text { legs } \\
\text { dynamometer } \\
(\mathrm{kg})\end{array}$ & $\varepsilon . Y r \varepsilon$ & $r .09$ & $\%^{\vee} .{ }^{\top 1}$ & $11.0 \leqslant$ & $1.99 \varepsilon$ & $\%$ YY.Y & $9 . \wedge 7 \%$ \\
\hline & $\begin{array}{c}\text { strength of } \\
\text { arms } \\
\text { dynamometer } \\
(\mathrm{kg}) \\
\end{array}$ & $\{. A V$ & $1.1 . \varepsilon$ & $\%$ ro. Ts & V.79v & 1.291 & $\% 77.09$ & A... \\
\hline & $\begin{array}{c}\text { Strength of } \\
\text { abdominal } \\
\text { muscles } \\
\text { Sit from lie } \\
\text { down } \\
\end{array}$ & T.YYO & $.90 r$ & $\% r^{\top}, r^{\prime}$ & T.Aגז & $1, r 11$ & $\% 7 r .11$ & $M . T H$ \\
\hline \multirow{3}{*}{ 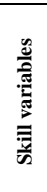 } & $\begin{array}{c}\text { Compatibility } \\
\text { Jump with } \\
\text { rope } \\
\end{array}$ & $\cdot{ }^{\mathrm{v}} \cdot$ & $.0 \times 1$ & $\%^{\circ} \cdot .$. & r.00. & .7174 & $\% 197.10$ & 9.170 \\
\hline & $\begin{array}{l}\text { Jump through } \\
\text { rope }\end{array}$ & $\varepsilon .9$. & $1 . \mathrm{TVY}$ & $\% \wedge \cdot, r r$ & 9.90. & $1.1 \leqslant 7$ & $\% 171$, . & rT. \\
\hline & $\begin{array}{l}\text { Throw and } \\
\text { catch }\end{array}$ & $£ .90$. & 1.571 & $\% \vee \vee . \vee \leqslant$ & $9.0 .$. & $1.1 \leqslant v$ & $\% 1 \leqslant 7.10$ & $1.9 T r$ \\
\hline
\end{tabular}

T. tabular value at the abstract level $0.05=2.042$

It is clear from table (8) that there are statistically significant differences between the averages of the two measurements pre and post for the two experimental and control group in physical and skill variables under discussion and in favor of the experimental group where that the $T$. value calculated is greater than the value of $T$. displayed, which amounted to 2.042 at the abstract level of 0.05 .

Researcher returns that to the experimental group Superiority on the control group in the results that compete with the performance 
of self-resistance body weight exercises, free performance is not loaded on the body of any additional burden. This was confirmed by each of the studies:

C., Joaquin, et al (2014) (4) and C., Anders (2012) (3)

\section{Conclusions}

Researcher concluded that:

1) TRX exercises benefit the students on performing the rhythmic technical exercise using rope.

2) TRX exercises using body weight resistant improved the performance level of total physical variables for body, because exercise combine upper and lower quarters of body.

3) the experimental group Superiority on the control group in the improvement percentage in physical abilities in strengthen muscles of (legsarms- abdominal) and Compatibility

\section{Recommendations}

1) Use TRX to improve physical abilities for physical education female students, because it is portable, easy to use.
2) Rhythmic gymnastics tools require to control on body muscles, and the especially the rope need Compatibility between legs and arms, which need extra tools or equipments in training.

3) Do future researches on devices and alternative tools to improve other physical abilities.

\section{References}

\section{Applying Suspension} Training to Football: nsca's performance training journal. 7 (4). Retrieved from: www.nsca-lift.org

\section{2.}

liss Lisa 2005. Core Stability the center piece of any Training program, American college of sport medicine.

\section{C., Anders \& M., Ninni}

(2012). Examining muscle activation for Hang Clean and three different TRX Power Exercises A validation study. Halmstad University

4. C., Joaquin, et al (2014). Muscle Activation during Push-Ups with Different Suspension Training Systems. Journal of Sports Science and Medicine. 13, 502- 
510. Retrieved from: http://www.jssm.org

8. Mohamed Sobhy 5. Federation

Hassanein (2004): Measurement and Evaluation Internationale De in Physical Education and Gymnastique (Fig) 2013 2016 code of points.

6. Fitness anywhere LLC (2011). Suspension training: sports medicine. U.S.A

7. Mohamed Sobhy Hassanein (2001):

Measurement and Evaluation in Physical Education and Sports, part I, 4, Dar el feqr el araby, Cairo. Sports, part I, 6, Dar el feqr el araby, Cairo.

9. Mufti

Ibrahim

Hammad2012:

Comprehensive reference in sports training, dar al-ketab alHades, Cairo.

10. http//en.sportclub.ahlamonat ada.com135-topic 